\title{
Molecular characterization of immunoinhibitory factors PD-1/PD-L1 in chickens infected with Marek's disease virus
}

\author{
Ayumi Matsuyama-Kato ${ }^{1}$, Shiro Murata ${ }^{1}$, Masayoshi Isezaki ${ }^{1}$, Rika Kano ${ }^{1}$, Sara Takasaki ${ }^{1}$, Osamu Ichii², \\ Satoru Konnai ${ }^{1}$ and Kazuhiko Ohashi ${ }^{\text {* }^{*}}$
}

\begin{abstract}
Background: An immunoinhibitory receptor, programmed death-1 (PD-1), and its ligand, programmed death-ligand 1 (PD-L1), are involved in immune evasion mechanisms for several pathogens causing chronic infections and for neoplastic diseases. However, little has been reported for the functions of these molecules in chickens. Thus, in this study, their expressions and roles were analyzed in chickens infected with Marek's disease virus (MDV), which induces immunosuppression in infected chickens.

Results: A chicken T cell line, Lee1, which constitutively produces IFN- $\gamma$ was co-cultured with DF-1 cells, which is a spontaneously immortalized chicken fibroblast cell line, transiently expressing PD-L1, and the IFN- $\gamma$ expression level was analyzed in the cell line by real-time RT-PCR. The IFN- $\gamma$ expression was significantly decreased in Lee1 cells co-cultured with DF-1 cells expressing PD-L1. The expression level of PD-1 was increased in chickens at the early cytolytic phase of the MDV infection, while the PD-L1 expression level was increased at the latent phase. In addition, the expression levels of PD-1 and PD-L1 were increased at tumor lesions found in MDV-challenged chickens. The expressions levels of PD-1 and PD- L1 were also increased in the spleens and tumors derived from MDV-infected chickens in the field.

Conclusions: We demonstrated that the chicken PD-1/PD-L1 pathway has immunoinhibitory functions, and PD-1 may be involved in MD pathogenesis at the early cytolytic phase of the MDV infection, whereas PD-L1 could contribute to the establishment and maintenance of MDV latency. We also observed the increased expressions of $P D-1$ and $P D-L 1$ in tumors from MDV-infected chickens, suggesting that tumor cells transformed by MDV highly express PD-1 and PD-L1 and thereby could evade from immune responses of the host.
\end{abstract}

\section{Background}

Marek's disease (MD) is a viral lymphoproliferative disease of chickens caused by a cell-associated herpesvirus, Marek's disease virus (MDV; family Herpesviridae, subfamily Alphaherpesvirinae, genus Mardivirus, species Gallid Herpesvirus 2 (GaHV-2)) [1]. MDV strains are classified into 3 serotypes, GaHV-2 (MDV serotype 1: MDV-1), Gallid herpesvirus 3 (MDV serotype 2: MDV-2) and Meleagrid herpesvirus 1 (MDV serotype 3 or herpesviru of turkeys (HVT)), and MD is caused by serotype1 MDV strains except for attenuated vaccine strains [1].

\footnotetext{
* Correspondence: okazu@vetmed.hokudai.ac.jp

${ }^{1}$ Department of Disease Control, Graduate School of Veterinary Medicine, Hokkaido University, Kita-18, Nishi-9, Kita-ku, Sapporo 060-0818, Japan Full list of author information is available at the end of the article
}

The pathogenesis of MD can be sequentially divided into 3 phases: early cytolytic phase, latent phase, and secondary cytolytic phase with immunosuppression and tumor development. In the early cytolytic phase, MDV-1 causes lytic infection of lymphoid cells, mainly B cells that last for up to six days after infection [2]. Then, this cytolytic infection induces the activation of $\mathrm{T}$ cells, and MDV establishes latency in a part of the activated $\mathrm{CD} 4^{+} \mathrm{T}$ cells at 1-2 weeks after infection. In the latent phase, infected chickens show no clinical signs, but cellular immunity is continually inhibited by apoptosis of $\mathrm{CD} 4^{+} \mathrm{T}$ cells, CD8down regulation in $\mathrm{CD}^{+} \mathrm{T}$ cells, decrease in the responsiveness to the stimulation through $\mathrm{T}$ cell receptor (TCR) in $\mathrm{CD}^{+}$and $\mathrm{CD}^{+} \mathrm{T}$ cells and MHC class I-down regulation at 2-3 weeks after infection [3,4]. In the secondary

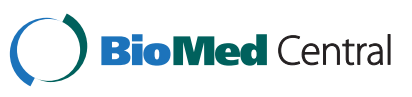


cytolytic phase, MDV-1 transforms a few latently infected $\mathrm{CD}^{+} \mathrm{T}$ cells, and develops malignant lymphomas. The main targets for the transformation by MDV-1 are $\mathrm{CD}_{4}^{+}$ $\mathrm{T}$ cells, suggesting that latent infection in this $\mathrm{T}$ cell subset is intimately related to the subsequent transformation by MDV-1 [1]. Several viral factors which could contribute to the oncogenicity and pathogenicity of MDV-1 have been identified. Among them, a viral protein, Meq, is the most important factor involved in MDV-1 oncogenicity [5-8]. Meq is only present in MDV-1 strains and is abundantly expressed in MDV-1-transformed cell lines and tumor samples. The overexpression of Meq in rodent and chicken fibroblast cell lines resulted in morphological changes of the cells and protection of the cells from apoptosis [6,7]. A Meq-deficient mutant virus was completely non-oncogenic [8]. These observations suggest that Meq plays a key role in the oncogenicity of MDV-1. However, the precise molecular mechanism of MDV-1 oncogenicity and pathogenicity remains to be established due to the lack of appropriate $\mathrm{T}$ cell transformation systems in chickens.

Currently, MD is well controlled by the vaccination with MDV-1 strains, apathogenic MDV-2 strains and/or HVT. However, MDV-1 strains in the field tend to increase their virulence, and increased numbers of MD cases have been reported even in vaccinated chickens [9]. Therefore, the development of more effective vaccines would be desirable, since future outbreaks of MDV-1 could occur [9]. However, the detailed mechanisms for the protection by vaccines are still unknown. It has been known that cell-mediated immunity is effective for the inhibition of MDV-1 propagation and oncogenicity [10]. The immune responses induced by MDV-1 inhibit virus propagation, whereas an excess of inflammatory response induces immunosuppression through a negative feedback mechanism, and subsequently contributes to MDV-1 reactivation from latency [11]. Thus, the host immune responses in infected chickens are also involved in the pathogenesis of MDV-1.

Persistent viral infections often result in T cell exhaustion. During chronic viral infection, such as human immunodeficiency virus (HIV) and hepatitis $\mathrm{C}$ virus $(\mathrm{HCV})$, antigen-specific $\mathrm{CD}^{+} \mathrm{T}$ cells initially obtain functional activities but gradually become dysfunctional as the infection progresses, and exhausted $\mathrm{CD}^{+} \mathrm{T}$ cells are unable to produce sufficient cytokines [12,13]. An immune inhibitory receptor, programmed death 1 (PD-1) and its ligand, programmed death ligand 1 (PD-L1), have been reported as molecules involved in $\mathrm{T}$ cell exhaustion [14]. PD-1 and PD-L1 belong to the B7-CD28 superfamily, and PD-1 is expressed on the membrane of activated T cells and B cells, while PD-L1 is constitutively expressed on the membrane of activated $\mathrm{T}$ cells, dendritic cells (DCs), macrophages, and a wide range of nonhematopoietic cells $[15,16]$. PD-1 expression is upregulated on $\mathrm{CD}^{+} \mathrm{T}$ cells specific for cells chronically infected with human T-cell lymphotropic virus type 1 (HTLV-1) [17]. The increase in PD-L1 expression was observed in cells infected with hepatitis B virus, HIV, and HTLV-1 [17-19]. In addition, the PD-1/ PD-L1 pathway plays a crucial role in immune evasion by tumor cells, such as pancreatic cancer and adult T-cell leukemia $[15,16]$.

Chicken PD-1 and PD-L1 shared 58\% and 54.5\% amino acid identities with human PD-1 and PD-L1, respectively, and the chicken $\mathrm{PD}-1 / \mathrm{PD}-\mathrm{L} 1$ pathway may also play roles in the immunoinhibitory functions. Recently, it has been reported that the expression levels of $P D-1$ and $P D-L 2$ mRNA on $C D 4^{+} \mathrm{T}$ cells were increased in the secondary cytolytic phase of the MDV-1 infection [20]. PD-L2, as well as PD-L1, belongs to the B7-CD28 superfamily, and is known to carry the immunoinhibitory functions by the interaction with PD-1 [21]. However, the PD-1/PD-L1 pathway usually serves as an immunoinhibitory molecule in human and murine diseases such as chronic infections and tumors, but not PD-L2. Therefore, it is necessary to analyze the expressions of PD-1 and PD-L1 in MDV-1-infected chickens and MD-derived tumors to properly know the roles of chicken immunoinhibitory molecules in MD pathogenesis and tumorigenesis. In this study, we evaluated the immunosuppressive functions of the PD-1/PD-L1 pathway, and analyzed the expression kinetics of the immunoinhibitory molecules in the spleens, peripheral blood mononuclear cells (PBMCs), and tumors of MDVinfected chickens. These results suggest that the chicken PD-1/PD-L1 pathway has immunosuppressive functions, and PD-1 and PD-L1 may contribute to MD pathogenesis and tumorigenesis.

\section{Results}

\section{Evaluation of the immunoinhibitory function of the} PD-1/PD-L1 pathway

In order to clarify the immunoinhibitory functions of chicken PD-1 and PD-L1, the expression level of IFN- $\gamma$ mRNA was measured in a chicken $\mathrm{T}$ cell line cocultured with cells expressing PD-L1. First, we measured the level of $P D-1$ mRNA expression in three chicken $\mathrm{T}$ cell lines, MSB1 and HP1, which were transformed by MDV-1, and Lee1, which was transformed by reticuloendotheliosis virus (REV), and PBMCs obtained from a healthy chicken (Figure 1A). PD-1 mRNA was highly expressed in Lee1 cells compared to other cells, and thus, Lee1 cells were used to evaluate the immunosuppressive functions of PD-1 and PD-L1. In this assay, we quantified the expression of IFN- $\gamma$ mRNA in Lee1 cells after the co-culture with a chicken fibroblast cell line, DF1, transfected with PD-L1-expressing vector, pCMV-PDL1 (Figure 1B), since REV-transformed $\mathrm{T}$ cells are known to constitutively produce IFN- $\gamma$ [22]. The expression of 
Figure 1 Analysis of immunoinhibitory functions by chicken PD-1/PD-L pathway. (A) The expression of PD-1 mRNA was determined in MSB1, HP1, Lee1 cell, and PBMCs from uninfected chickens by real-time RT-PCR. The degree of the PD-1 mRNA expression was expressed relative to the mean basal value in PBMCs after normalization to that of $\beta$-actin mRNA. (B) The expression levels of IFN- $\gamma$ mRNA in Lee1 cells co-cultured with DF-1 cells were determined by real-time RT-PCR. DF-1 cells were transfected with pCMV-Tag1 or PCMV-PDL1. The degree of the PD-1 and IFN- $\gamma$ mRNA expression was expressed relative to the mean basal value in the presence of $\mathrm{pCMV}$-Tag1 after normalization to that of $\beta$-actin mRNA. Three independent experiments were performed in triplicate. Error bars indicate standard deviations. The significant differences were determined by Student's paired $t$-test between types of expression plasmids (*P<0.05). (C) Transient expression of PD-L1 construct in DF-1 cells was determined by western blotting. Blots were also probed with an anti-actin monoclonal antibody as a loading control.

B

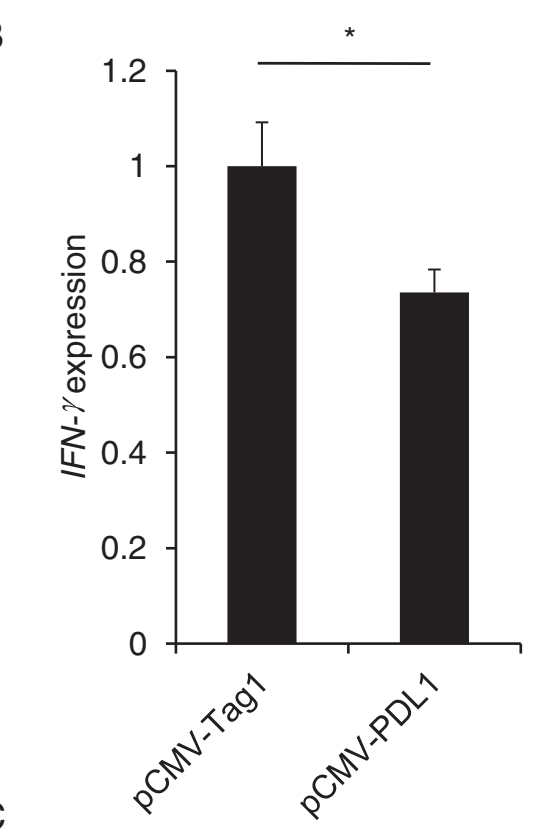

C
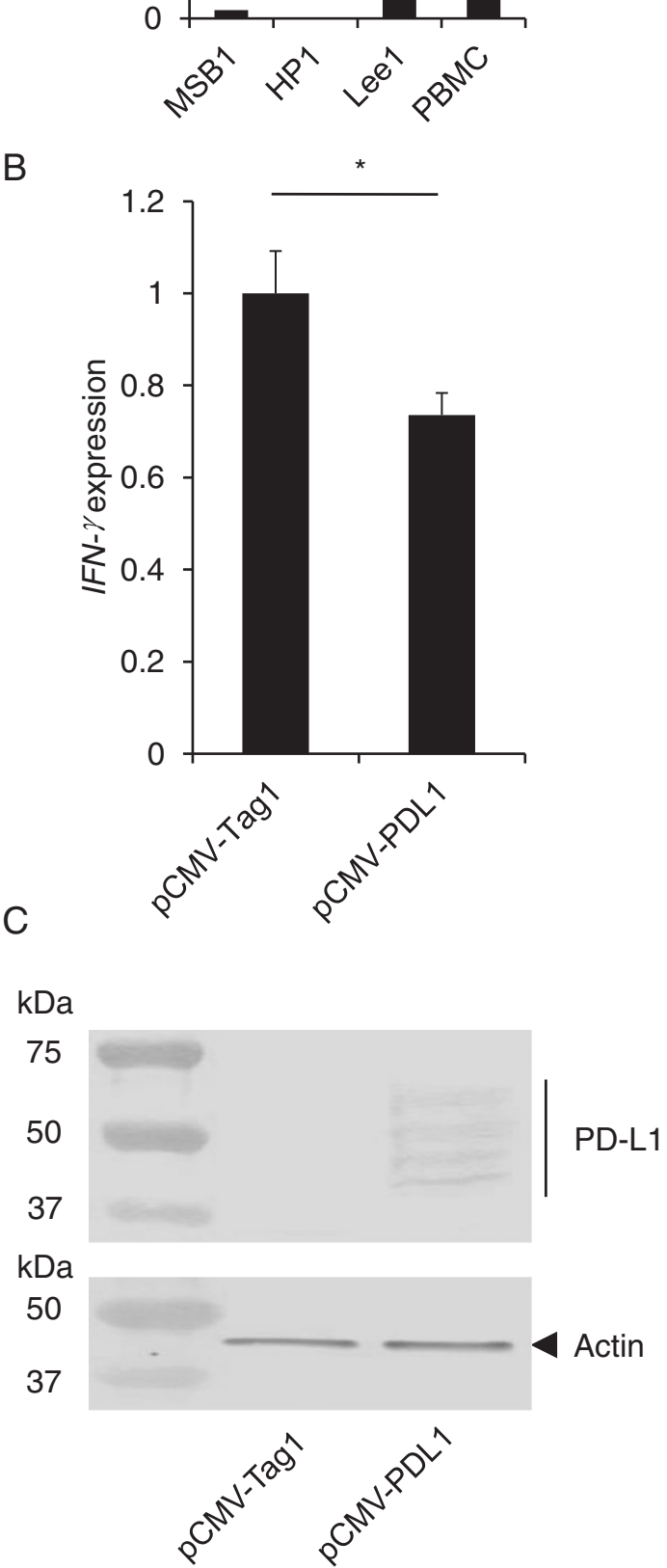

Figure 1 (See legend on next column.)
IFN- $\gamma$ mRNA was reduced in Lee1 cells co-cultured with pCMV-PDL1-transfected DF-1 cells compared to pCMVTag1-transfected DF-1 cells. The transient expression of PD-L1 in pCMV-PDL1-transfected DF-1 cells was confirmed by Western blotting (Figure 1C). These results suggest that the PD-1/PD-L1 pathway exhibits the immunosuppressive functions.

MDV loads and the expressions of PD-1, PD-L1, IFN $\gamma$, and meq mRNA in experimentally infected chickens

To investigate whether immunoinhibitory molecules are involved in MD pathogenesis, we analyzed viral loads and expression levels of host and viral genes in the spleens of MDV-1-infected chickens. First, the MDV-1 genome loads were quantified at 3, 7, 10, 14, 21, 28, and 35 day post inoculation (d.p.i) (Figure 2). The MDV-1 genome was detected in all of samples from infected

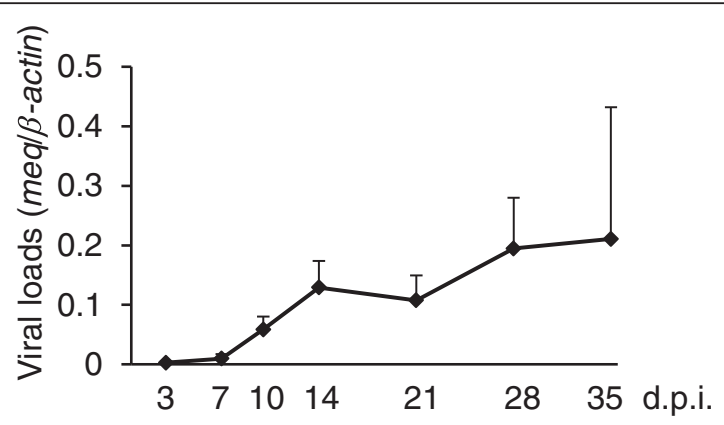

Figure 2 Viral loads in spleens from chickens experimentally infected with MDV-1. Chickens were inoculated with 2,000 PFU of RB1B ( $n=36)$. Spleens were collected from MDV-1-infected and uninfected chickens at 3, 7, 10, 14, 21, 28, and 35 d.p.i., and four samples were prepared at each time point. Viral loads in the spleens were determined by real-time PCR targeting the mea gene. The results are shown as ratios between concentrations of the mea and chicken $\beta$-actin genes in the spleens. Error bars indicate standard deviations. 
chickens throughout the experimental period. The viral load was increased at 14 d.p.i., decreased slightly at $21 \mathrm{~d}$. p.i., and increased again at 28 d.p.i. In our experiments, based on the amounts of the MDV-1 genome at each time point after virus inoculation, we determined each phase of the MDV infection: the early cytolytic phase (7-14 d.p.i.), the latent phase (14-28 d.p.i.), and the secondary cytolytic phase (after 28 d.p.i.). The expression of $P D-1$ mRNA was upregulated in the early cytolytic phase, whereas the expression of $P D-L 1$ mRNA was transiently increased in the early cytolytic phase (at 7 d.p.i.) and increased again in the latent phase (at 21 d.p.i.) (Figure 3A, B). Since IFN- $\gamma$ could be involved in the expressions of PD-1 and PD-L1 [14,15], the expression of IFN- $\gamma$ mRNA was also analyzed (Figure $3 C$ ). The expression of IFN- $\gamma$ mRNA was increased in the early infection phase (at 7-14 d.p.i.), decreased in the latent phase following the increase in the expression of $P D-L 1$ mRNA, and increased again in the secondary cytolytic phase.

In recent studies, it was reported that the HIV accessory protein Nef or the $\mathrm{HCV}$ core protein could upregulate PD-1 expression [23,24]. Since an MDV-1 oncoprotein, Meq, contributes to oncogenicity by altering the expression of various cellular genes [6] and also plays an important role in the induction of immunosuppression [25], Meq may be involved in the expression of PD-1 in MDV-1-infected chicken. In addition, Meq is abundantly expressed in latently-infected cells and tumor cells [5], and therefore, Meq may be also involved in the expression of PD-L1. Thus, we analyzed the expression of meq mRNA in each phase of the infection (Figure 3D). The expression of meq mRNA was increased at 14 d.p.i., and this expression kinetics were similar to those of $P D-1$ mRNA in the early cytolytic phase. However, the expression of meq mRNA was increased again in the secondary cytolytic phase, unlike the kinetics of $P D-1$ mRNA, because MDV-1 was reactivated following the disease progression (Figure 2).

\section{Expressions of $P D-1, P D-L 1, I F N \gamma$, and meq mRNA in tumor lesions}

To examine if immunoinhibitory molecules could be involved in tumor formation by MDV-1, the mRNA expressions of $P D-1, P D-L 1, I F N-\gamma$, and meq were analyzed in tumor lesions observed in kidneys of experimentally infected chickens (Figure 4). The expressions of $P D-1$ and $I F N-\gamma$ in tumor lesions were significantly increased, and the mean degree of the expression of $P D$ $L 1$ was increased although the difference was not statistically significant. In addition, the expressions of $P D-1$ and $P D-L 1$ in tumor lesions were compared with those in PBMCs obtained from experimentally infected chickens (Additional file 1: Figure S1). The expressions of $P D-1$ and $P D-L 1$ in tumor lesions were significantly
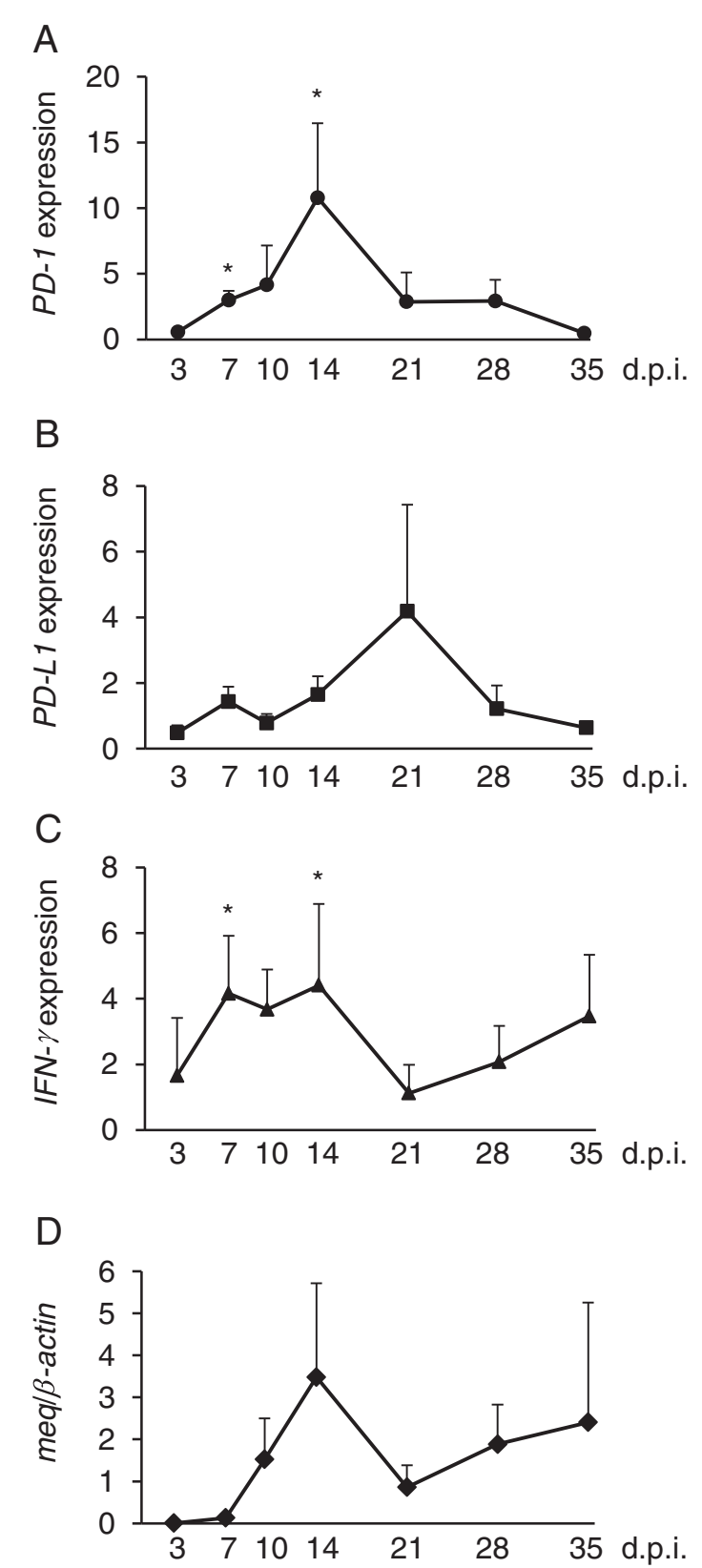

Figure 3 The mRNA expressions of $P D-1$ and $P D-L 1$ in the spleens from chickens experimentally infected with MDV-1. The expressions of PD-1 (A), PD-LI (B), IFN- $\gamma(\mathbf{C})$, and meq (D) MRNA were determined by real-time RT-PCR. The results are presented as mean and standard deviations in each schedule. The concentration of each mRNA (A-C) was normalized to that of $\beta$-actin mRNA.

The extent of gene expression (-fold) was calculated by dividing the value of each sample by that of each control. The significant differences were determined by Student's t-test ( $\left.{ }^{*} P<0.05\right)$.

increased compared to those in PBMCs. These results suggest that PD-1 and PD-L1 were expressed on tumor cells caused by MDV-1. In tumor cells, there was a positive correlation between $m e q$ and $P D-1$ mRNA expressions (Figure 5A), or between $P D-L 1$ and $I F N-\gamma$ mRNA 


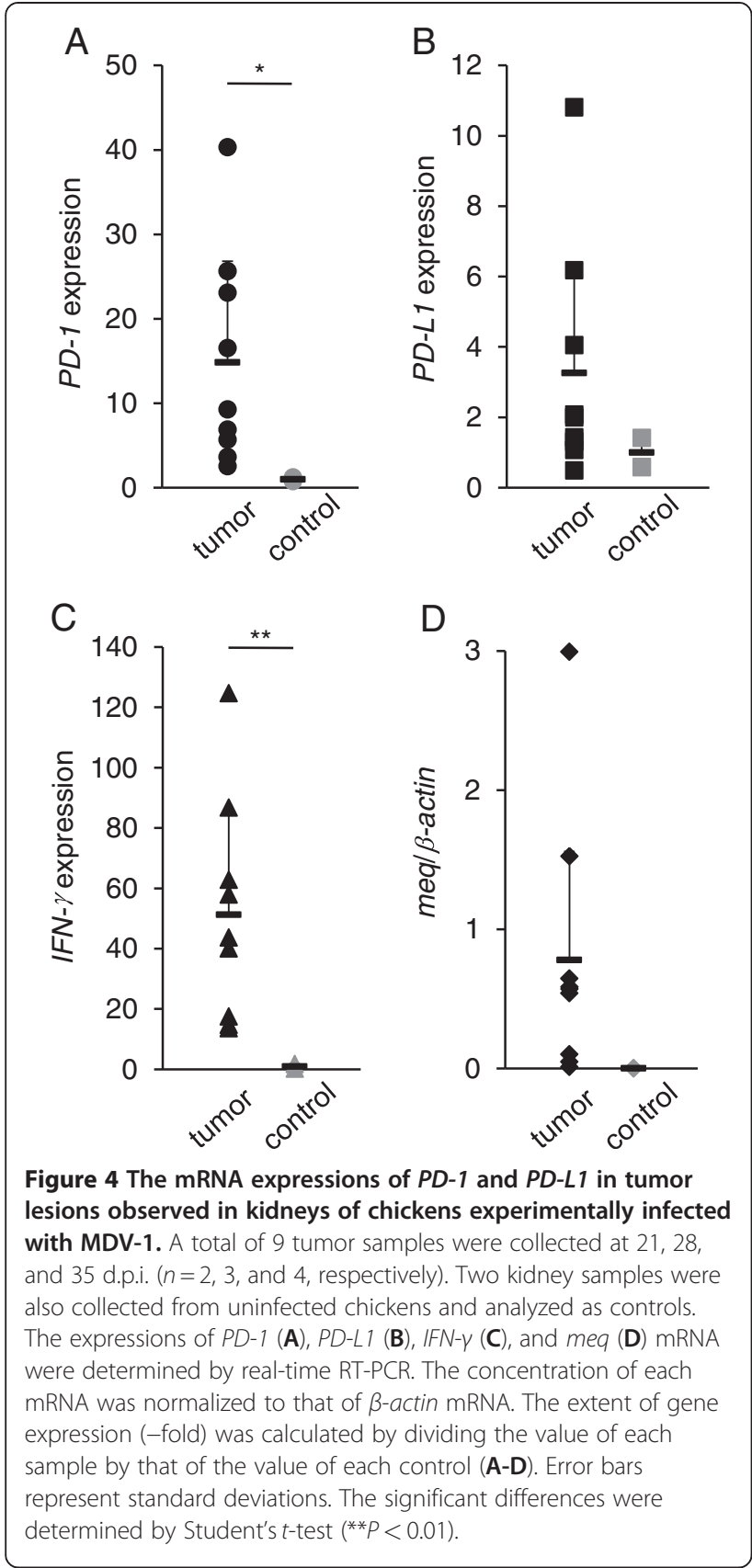

expressions (Figure 5B). However, no correlation was shown between the MDV-1 genome and the expressions of PD-1 or PD-L1. The Spearman correlation coefficient between the MDV-1 genome and PD-1 or PD-L1 was $0.18(p=0.64)$ and $0.050(p=0.90)$, respectively.

\section{Expressions of $P D-1, P D-L 1, I F N Y$, and meq mRNA in the spleens and tumor lesions derived from chickens with MD in the field}

To examine if immunoinhibitory molecules are expressed in chickens developing $\mathrm{MD}$ in the field as observed in
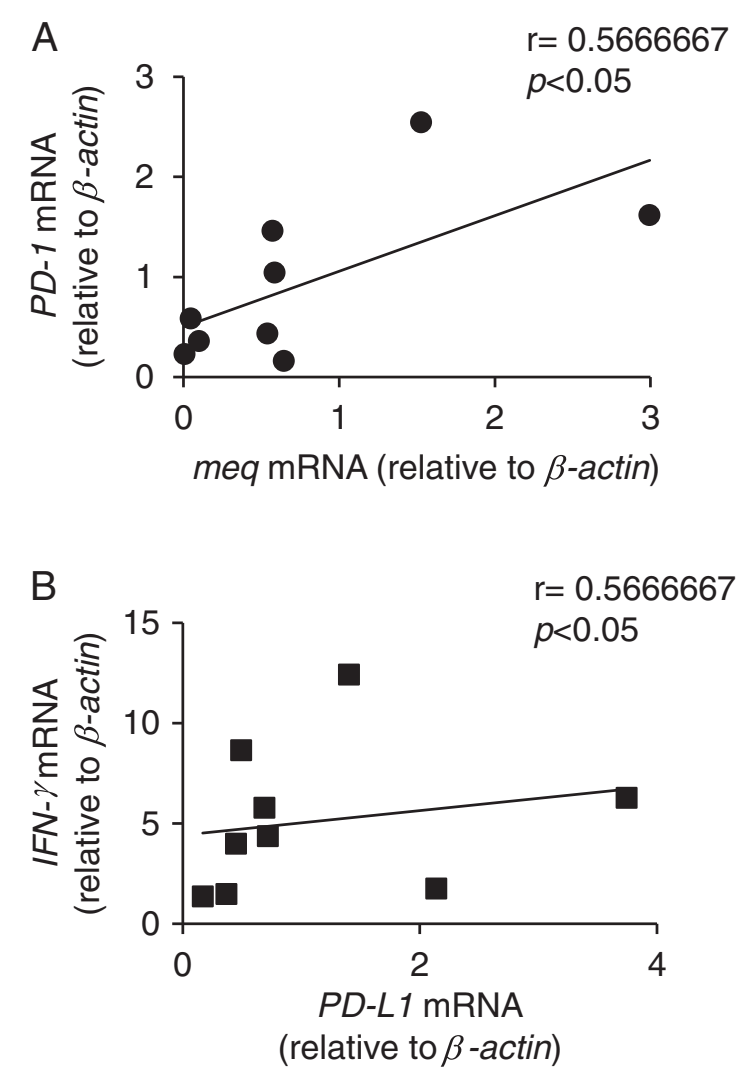

Figure 5 A positive correlation between each of the gene expressions in MD-derived tumor samples. These data are shown correlations between gene expressions of meq and PD-1 (A), and $P D-L 1$ and IFN- $\gamma(B$ B). r, Spearman's correlation coefficient.

those of experimentally infected chickens, we measured the mRNA expressions of the meq gene and host genes in the spleens and tumor lesions derived from chickens with MD in the field (Figures 6 and 7). The expression of meq RNA was observed in all of the field samples, and the mean degree of the mRNA expressions of $P D-1, P D-L 1$ and IFN- $\gamma$ was also increased. Thus, in the case of chickens with MD in the field, the mRNA expressions of $P D-1$ and $P D-L 1$ were similar to those observed in experimentally infected chickens.

in situ detection of $P D-1, P D-L 1$, and meq mRNA in tumors derived from MDV-infected chickens

To further determine if these host genes and the meq gene were expressed in MD tumor cells, the histological analysis was conducted by in situ hybridization. Since the meq gene is abundantly expressed even in latentlyinfected and transformed cells, it seems to be an optimal marker for the detection of MDV-infected cells. In tumor lesions, the meq transcripts were detected in cells infiltrating into the interstitial of kidney tubule, and in the spleen, meq transcripts were detected in white pulp (Figure 8A). These results indicate that MDV-1-infected 


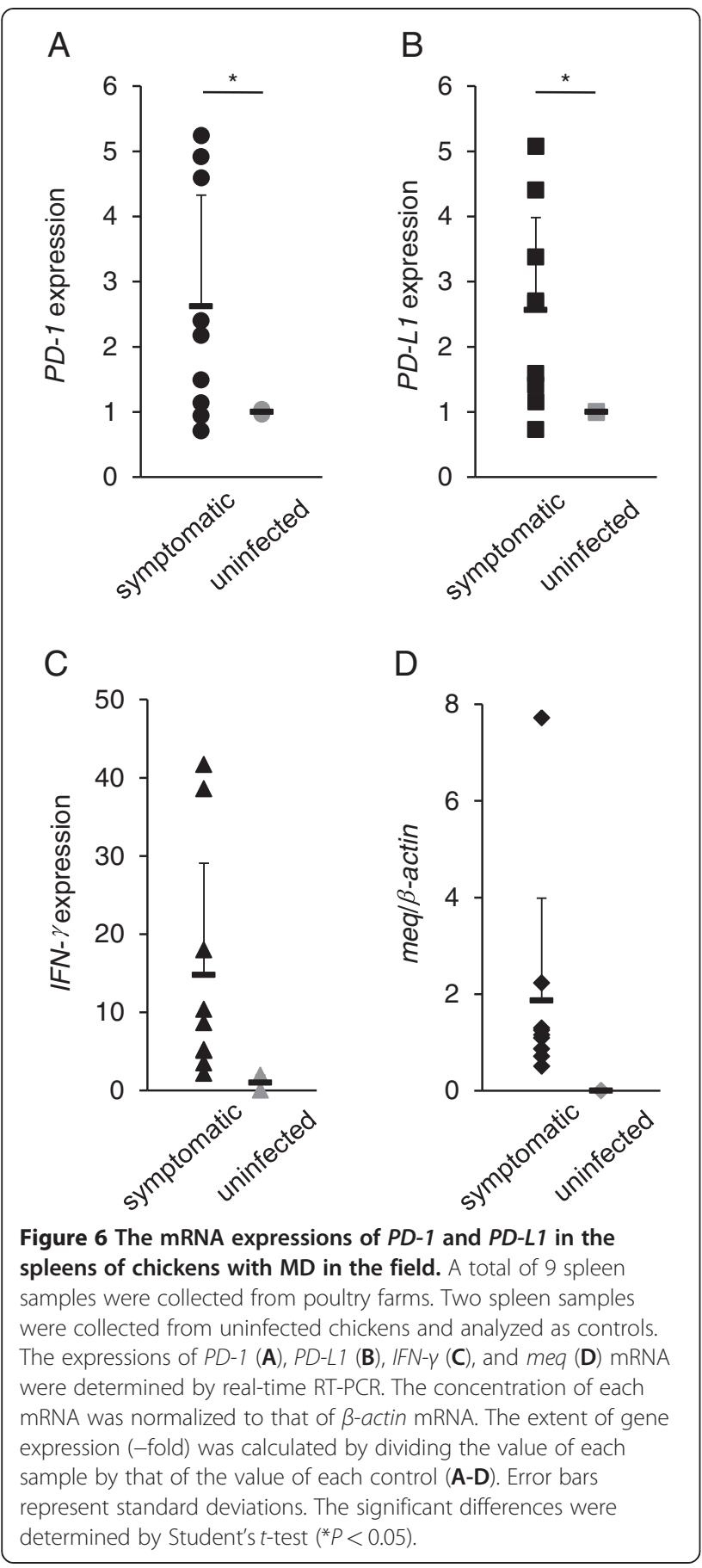

cells could be detected by in situ hybridization analysis. However, the $P D-L 1$ transcripts were undetectable in the spleen and tumor lesions by in situ hybridization analysis (data not shown). In order to confirm the mRNA expressions of $P D-1$ and $P D-L 1$ in tumor cells, nested RT-PCR assays were performed by using laser-captured microdissections (Figure 8B, C). The mRNA expressions of $P D-1$ and $P D-L 1$ were observed in tumor cells. These results showed that both $P D-1$ and $P D-L 1$ mRNA

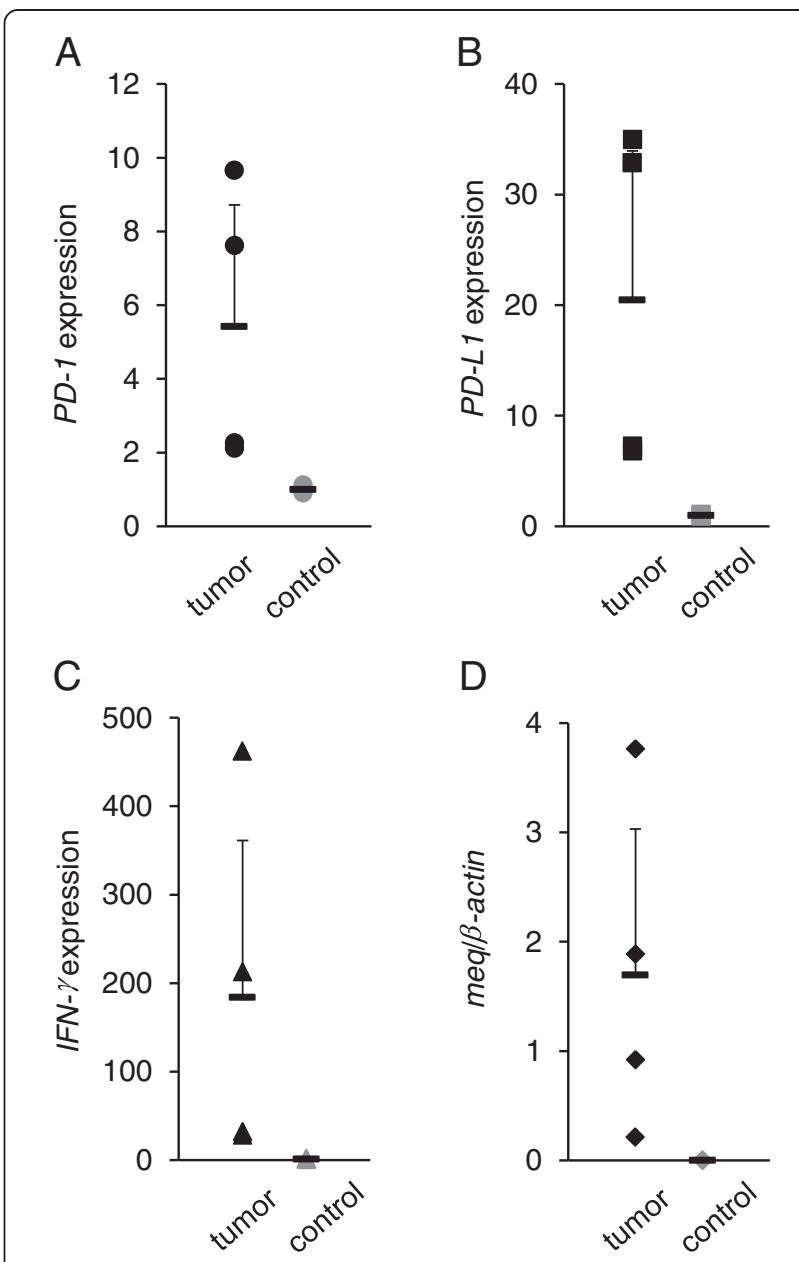

Figure 7 The mRNA expressions of $P D-1$ and $P D-L 1$ in tumor samples of chickens with MD in the field. A total of 4 tumor samples were analyzed, and then, PBMCs from uninfected chickens $(n=3)$ were also analyzed as controls. The expressions of PD-1 $(\mathbf{A})$,

PD-L1 (B), IFN- - (C), and mea (D) MRNA were determined by real-time RT-PCR. The concentration of each mRNA was normalized to that of $\beta$-actin mRNA. The extent of gene expression (-fold) was calculated by dividing the value of each sample by that of the value of each control (A-D). Error bars represent standard deviations.

were expressed in MD-derived tumor cells, and may contribute to immune evasion of tumor cells from host immune responses.

\section{Discussion}

Recent studies have shown that host immunoinhibitory factors, such as PD-1 and PD-L1, are exploited to evade the immune response in chronic viral infections [26,27]. However, the function of the chicken PD-1/PD-L1 pathway has not been well characterized. In order to evaluate immunosuppressive function of PD-1 / PD-L1 pathway, we determined the expression level of IFN- $\gamma$ mRNA in Lee1 cells which was co-cultured with DF-1 expressing PD-L1. The expression of IFN- $\gamma$ mRNA was decreased 


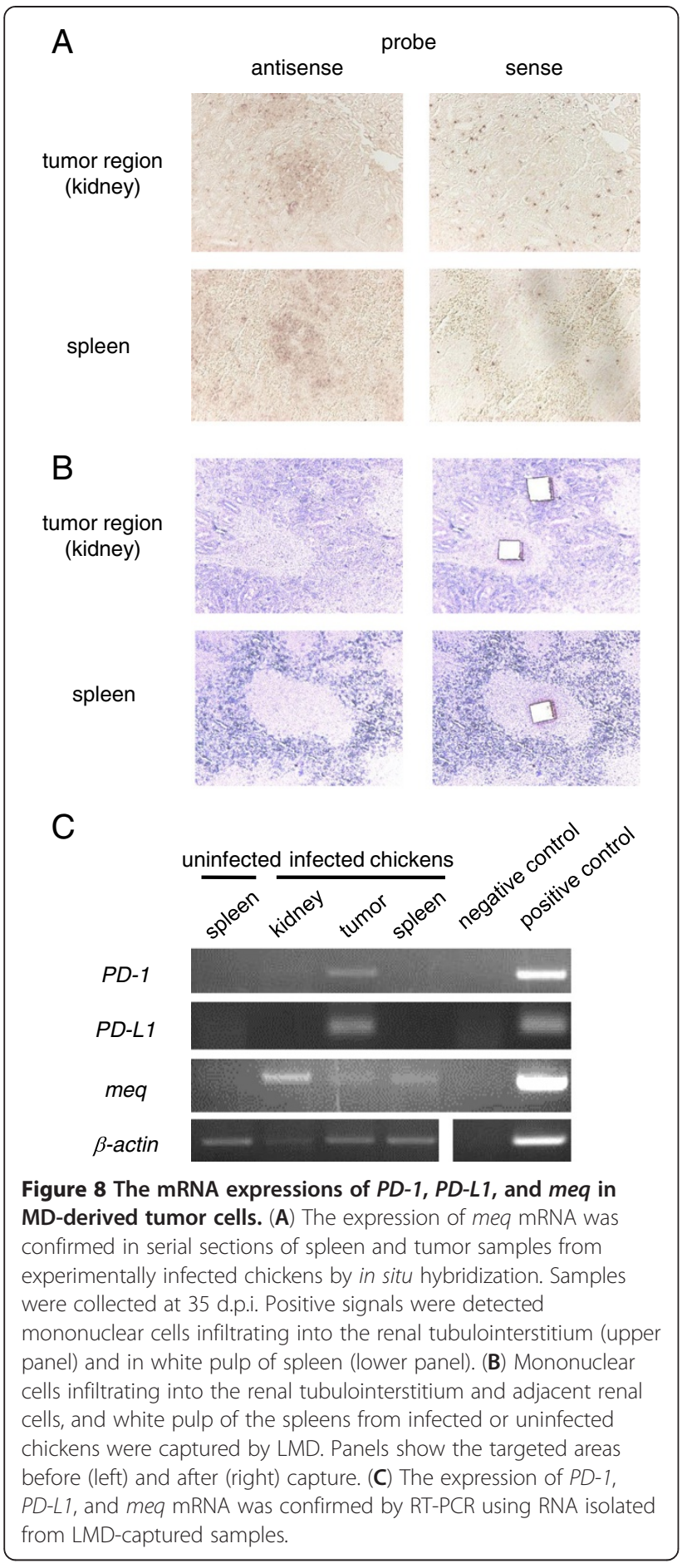

in Lee1 cells co-cultured with DF-1 expressing PD-L1, suggesting that in case of chickens, PD-L1 also interacts with PD-1, and then induces the immunosuppression in PD-1-expressing cells, although further functional analysis concerning the involvement of chickens PD-1/ PD-L1 pathway in immunosuppression and tumor formation is required.
The increase in PD-1 expression was reported in the acute phase of $\mathrm{HCV}$ and lymphocytic choriomeningitis virus (LCMV) infection [26,27]. In chickens experimentally infected with MDV-1, the expression of $P D-1$ mRNA was increased in the early cytolytic phase, but dramatically decreased following the onset of the latent infection (Figure 3A). We previously reported that MDV-1 induces apoptosis in $\mathrm{CD} 4^{+} \mathrm{T}$ cells during latent phase, and the number of $\mathrm{CD} 4^{+} \mathrm{T}$ cells is decreased [28]. These observations suggest that PD-1 may be expressed on the $\mathrm{CD} 4^{+} \mathrm{T}$ cells in the early cytolytic phase, and the expression of PD-1 may be decreased by apoptosis of $\mathrm{CD} 4{ }^{+} \mathrm{T}$ cells before the onset of MDV latency. In contrast, the increase in $P D-L 1$ mRNA expression was observed in the latent phase (Figure $3 \mathrm{~B}$ ), suggesting that PD-L1 contribute to the establishment and/or maintenance of MDV-1 latency. Further studies, including the identification of PD-1- and PD-L1-expressing cell populations and the expression analysis of PD-1 and PD-L1 on the protein level, are needed to clarify the role of the PD-1/PD-L1 pathway in each phase of the infection.

In the case of HIV infection, some cytokines and viral factors are considered to be responsible for the increase in PD-1 and PD-L1 expressions [29], and it has been well characterized that PD-L1 expression could be regulated by IFN- $\gamma$ [15]. In this study, the expression of IFN- $\gamma$ mRNA was increased in the early cytolytic phase, and this expression kinetics was similar to that of PD-1 mRNA (Figure 3C), suggesting that IFN- $\gamma$ may be involved in the regulation of PD-1 expression. However, the increase in the PD-1 mRNA expression was not observed in the secondary cytolytic phase despite the increase in the IFN- $\gamma$ expression. Thus, PD-1 expression may be induced as a consequence of a negative feedback by IFN- $\gamma$ stimulation during the acute phase. On the contrary, the expression of $P D-L 1$ mRNA was transiently elevated at 7 d.p.i., and then, the expression of IFN- $\gamma$ mRNA was increased (Figure 3B, C). At 21 d.p.i., however, PD-L1 mRNA expression were increased again although IFN- $\gamma$ mRNA expression was decreased (Figure 3B, C). The reason for these observations is unknown, but IFN- $\gamma$ might gradually induce the expression of PD-L1, which, in turn, cause immunosuppression and reduce the IFN- $\gamma$ expression.

PD-L1 is expressed on a variety of human and murine tumors [30], whereas tumor-infiltrating lymphocytes highly express PD-1 [31]. In the case of nodular lymphocytepredominant Hodgkin lymphoma and angioimmunoblastic T-cell lymphoma, tumor cells express PD-1 [32,33]. Moreover, tumor cells caused by HTLV-1 express both PD-1 and PD-L1, and infiltrating T cells express PD-1, suggesting that PD-L1 expressed on these neoplastic $\mathrm{CD}^{+} \mathrm{T}$ cells induce immunosuppression of infiltrating $\mathrm{T}$ cells and contribute to the immune evasion [34]. In the case of MDV-1 infection, both PD-1 and PD-L1 mRNA 
expression were increased in tumor cells (Figure 4A, B, Figure 7A, B, Figure 8C, Additional file 1: Figure S1). Thus, both PD-1 and PD-L1 may be expressed on MD tumor cells, and may contribute to the immune evasion. Interestingly, the expression of IFN- $\gamma$ mRNA was increased in tumor lesions (Figure 4C), and the expression of $I F N-\gamma$ mRNA in tumor lesions was higher than that in neighboring cells (data not shown). As a positive correlation was shown between IFN- $\gamma$ and $P D-L 1$ mRNA expressions (Figure 5B), IFN- $\gamma$ may upregulate the expression of $P D-L 1$ mRNA in tumor cells in an autocrine manner, and subsequently, PD-L1 may enhance the immunosuppression.

Several groups reported that viral proteins such as Nef protein of HIV and core protein of HCV cause the increase in PD-1 expression [23,24]. In this study, we focused on an MDV-1 oncoprotein, Meq, because Meq regulates the expressions of various genes as a transcription factor and is the most important viral factor related to $\mathrm{MD}$ pathogenesis $[8,35]$. The expressions of meq and $P D-1$ mRNA were transiently increased at 14 d.p.i (Figure 3A, D), and in addition, the expression of meq mRNA was positively correlated with $P D-1$ mRNA expression in tumor lesions (Figure 5A), indicating that Meq may regulate the expression of PD-1. However, a positive correlation between the expression of $m e q$ and $P D-L 1$ was not observed in the spleens and tumors from MDV-1-infected chickens. Since various viral factors are involved in MDV-1 oncogenesis and pathogenesis [35], other factors may correlate with the expressions of host immunoinhibitory molecules.

In summary, we demonstrated that host immunoinhibitory factors, PD-1 and PD-L1 were expressed in the spleens of MDV-1-infected chickens, and their expressions were showed different kinetics in each phase of the infection (Additional file 2: Figure S2). Furthermore, these factors were expressed in MD-derived tumors (Additional file 2: Figure S2). These results suggest that the PD-1/PD-L1 pathwayis involved in the immunosuppression and tumor formation by MDV-1.

\section{Materials \& methods}

Cells

MD-derived lymphoblastoid cell lines, MSB1 [36] and HP1 [37], and chicken T-cell line, Lee1, that was transformed by REV and was established in our laboratory, were maintained at $41^{\circ} \mathrm{C}, 5 \% \mathrm{CO}_{2}$ in RPMI 1640 (SigmaAldrich Co., St. Louis, USA) supplemented with $10 \%$ heat-inactivated fetal bovine serum (FBS; Invitrogen, Carlsbad, USA), 0.03\% L-glutamine, $100 \mathrm{U} / \mathrm{ml}$ penicillin, $100 \mu \mathrm{g} / \mathrm{ml}$ streptomycin and $50 \mu \mathrm{M}$ 2-mercaptoethanol. Chicken embryo fibroblasts (CEFs) were prepared from 11-day-old fertile eggs (Hokuren Co. Ltd, Sapporo, Japan) and maintained at $37^{\circ} \mathrm{C}, 5 \% \mathrm{CO}_{2}$ in Eagle's Minimum Essential Medium (Nissui, Tokyo, Japan) supplemented with
10\% Tryptose phosphate broth (Difco Laboratories, Detroit, USA), 0.03\% L-glutamine, $100 \mathrm{U} / \mathrm{ml}$ penicillin, $100 \mu \mathrm{g} / \mathrm{ml}$ streptomycin and $0.1 \% \mathrm{NaHCO}_{3}$. The immortalized CEF cell line, DF-1 [38], was maintained at $39^{\circ} \mathrm{C}$, $5 \% \mathrm{CO}_{2}$ in Dulbecco's modified Eagle's Medium (DMEM; Invitrogen) supplemented with 10\% FBS, 0.03\% Lglutamine, $100 \mathrm{U} / \mathrm{ml}$ penicillin, $100 \mu \mathrm{g} / \mathrm{ml}$ streptomycin and $0.1 \% \mathrm{NaHCO}_{3}$.

\section{Chickens}

Neonatal male White Leghorn chickens were purchased from Hokuren Co. Ltd., and raised in isolators. The flock was free of common poultry diseases and not vaccinated against MDV. Feed and water were provided ad libitum.

\section{Virus}

A strain of very virulent MDV-1, RB1B [39], was obtained from chicken kidney cell culture taken from experimentally infected chickens in our laboratory. This virus was propagated in CEFs and virus titer was determined by plaque assays as described previously [40]. These infected CEFs were used for the viral inoculation of chickens. Strain RB1B at passage 12 was used in this study.

\section{Virus inoculation and sample collection from experimentally infected chickens}

Two groups of 5-day-old chickens (36 chickens/group) were inoculated intraperitoneally with either 2,000 plaque forming unit (PFU)/0.2 ml of RB1B or $0.2 \mathrm{ml}$ of PBS as untreated controls. Spleens and PBMCs were collected from chickens in each group at 3, 7, 10, 14, 21, 28, and 35 d.p.i. Four samples per group were prepared at each time point. Each sample was a composite from two chickens at 3 d.p.i., because the number of cells collected from one chicken was too few to be examined. At 7 to 35 d.p.i. each sample was obtained from only one chicken. In addition, tumor lesions, which were observed in kidneys of MDV-1-infected chickens after 21 d.p.i., were also collected. This study was conducted in accordance with guidelines of the Institutional Animal Care and Use Committee of Hokkaido University, Japan.

\section{Samples of chickens with MD in the field}

Samples of chickens with MD in the field were collected from poultry farms in Japan in 2010. Nine spleen- and 4 tumor-samples were used in this study. Of these tumor samples, one was observed in a spleen and the others were observed in livers.

\section{Evaluation of viral loads in MDV-1-infected chickens by real-time PCR}

The absolute MDV-1 genome loads in the spleens and tumor lesions were quantified using real-time PCR with primers specific to the meq gene of MDV-1 as described 
elsewhere [41]. The sequences of the meq primers are shown in Table 1. Total cellular DNA was extracted using the Sepa Gene kit (Sanko Jyunyaku Co. Ltd., Tokyo, Japan) according to the manufacturer's instructions. Realtime PCR assays were performed using SYBR Premix DimerEraser (Takara, Shiga, Japan) and a LightCycler 480 System II (Roche Diagnostics, Mannheim, Germany). The chicken $\beta$-actin gene in each sample was also amplified using a primer pair in Table 1 . The $\beta$-actin gene was used as a reference for the meq gene in each sample to express the ratio between the two genes. Each sample was tested in duplicate and the data were presented as average.

\section{Total cellular RNA extraction and cDNA synthesis}

Total cellular RNA was extracted from MSB1, HP1, and Lee1 cells, PBMCs obtained from a healthy chicken, and the spleen and tumor samples from experimentally infected chickens and from chickens with MD in the field, using the TRIZOL reagent (Invitrogen) according to the manufacturer's protocol. Each RNA sample was treated with DNase I (Invitrogen) to remove residual DNA, and cDNA was synthesized with Moloney murine leukemia virus reverse transcriptase (Takara) as directed by the manufacturer.

\section{Expression analyses of the PD-1, PD-L1, IFN- $\gamma$, and meq} mRNA by real-time RT-PCR

Synthesized cDNA samples were used to determine the mRNA expression levels of related factors by real-time
RT-PCR. The cDNA template was added to a total volume of $20 \mu \mathrm{l}$ containing PCR buffer, oligonucleotide primers at $0.3 \mu \mathrm{M}$ each of primer, and $10 \mu \mathrm{l}$ of SYBR Premix DimerEraser. Real-time RT-PCR assays were performed using the LightCycler 480 System II (Roche Diagnostics). The sequences of specific primers and accession numbers for $P D-1, P D-L 1$, and $I F N-\gamma$ are listed in Table 1, and meq as described above. The cycling condition consists of initial template denaturing at $95^{\circ} \mathrm{C}$ for $30 \mathrm{~s}$, followed by amplification of template for 35 cycles $(\beta$-actin) or 40 cycles $(P D-1, P D-L 1$, $I F N-\gamma$, and meq) of $95^{\circ} \mathrm{C} 5 \mathrm{~s}, 55^{\circ} \mathrm{C}$ for $30 \mathrm{~s}$, and $72^{\circ} \mathrm{C}$ for $30 \mathrm{~s}$. A final melting curve analysis was performed from $65^{\circ} \mathrm{C}$ to $95^{\circ} \mathrm{C}$ at a rate of $0.11^{\circ} \mathrm{C} / \mathrm{s}$ (continuous acquisition), with a final cooling to $40^{\circ} \mathrm{C}$ over $10 \mathrm{~s}$. The specificity of amplification was confirmed by melting point analysis. The chicken $\beta$-actin gene in each sample was also amplified using a primer pair in Table 1 . The $\beta$-actin gene was used as reference for target genes in each sample to express the ratio between the two genes. Serial dilutions of pGEM-T easy vector (Promega, Madison, WI, USA) encoding each gene $\left(1 \times 10^{-6}\right.$ to $1 \mathrm{ng} / \mathrm{ml}$ ) were used to generate standard curves for quantification. All primers were BLAST-searched against chicken DNA sequences available in GenBank to ensure amplification specificity and synthesized by Hokkaido System Science (Sapporo, Japan). All samples were tested in duplicate and the data were presented as average. Results were expressed in folds of each mRNA

Table 1 Primers used for real-time PCR, real-time RT-PCR, and LMD and RT-PCR

\begin{tabular}{|c|c|c|c|c|c|}
\hline Genes & Analysis & Types & Sequences & $\begin{array}{l}\text { Annealing temperature } \\
\text { for LMD and RT-PCR } \\
\text { analysis }\end{array}$ & $\begin{array}{l}\text { Accession } \\
\text { number }\end{array}$ \\
\hline \multirow[t]{3}{*}{ meq } & real-time PCR & Forward & 5'-GTCCCCCCTCGATCTTTCTC-3' & $60^{\circ} \mathrm{C}$ & AY362736 \\
\hline & real-time RT-PCR & Reverse & 5'-CGTCTGCTTCCTGCGTCTTC-3' & & \\
\hline & LMD and RT-PCR & & & & \\
\hline \multirow[t]{2}{*}{$\beta$-actin } & real-time $P C R$ & Forward & 5'-GAGAAATTGTGCGTGACATCA-3' & $55^{\circ} \mathrm{C}$ & L08165 \\
\hline & & Reverse & 5'-CCTGAACCTCTCATTGCCA-3' & & \\
\hline \multirow[t]{2}{*}{$\beta$-actin } & real-time RT-PCR & Forward & 5'-CCAACTGGGATGATATGGAGAAG-3' & $58^{\circ} \mathrm{C}$ & NM205518 \\
\hline & LMD and RT-PCR & Reverse & 5'-AGGCATACAGGGACAGCACA-3' & & \\
\hline \multirow[t]{2}{*}{$P D-1$} & real-time RT-PCR & Forward & 5'-GGACTACGGTGTGCTGGAGTT-3' & $60^{\circ} \mathrm{C}$ & XM422723 \\
\hline & LMD and nested RT-PCR (2nd PCR) & Reverse & 5'-TCTTTCCTCGCTCTGGTGTG-3' & & \\
\hline$P D-1$ & LMD and nested RT-PCR (1st PCR) & Forward & 5'-ACACCCTGGCGGAGGTGAAG-3' & $60^{\circ} \mathrm{C}$ & XM422723 \\
\hline (1st PCR) & & Reverse & 5'-TGCCAGGTCCTCTGATCGTTGTG-3' & & \\
\hline \multirow[t]{2}{*}{$P D-L 1$} & real-time RT-PCR & Forward & 5'-TTCAGGGACGGATAAAGCTG-3' & $60^{\circ} \mathrm{C}$ & XM424811 \\
\hline & LMD and nested RT-PCR (2nd PCR) & Reverse & 5'-CGTCTCTGAGCTTCACGTTG-3' & & \\
\hline$P D-L 1$ & LMD and nested RT-PCR (1st PCR) & Forward & 5'-GGGACTTAAGCGTCATCTGGGAA-3' & $58^{\circ} \mathrm{C}$ & XM424811 \\
\hline (1st PCR) & & Reverse & 5'-GGTAAAGCCCCGCGTCTCTG-3' & & \\
\hline \multirow[t]{2}{*}{ IFN- $\gamma$} & real-time RT-PCR & Forward & 5'-CTCCCGATGAACGACTTGAG-3' & $58^{\circ} \mathrm{C}$ & NM205149 \\
\hline & & Reverse & 5'-CTGAGACTGGCTCCTTTTCC-3' & & \\
\hline
\end{tabular}


expression compared to those in PBMCs or spleens of uninfected chickens.

\section{in situ hybridization analysis}

cRNA probes for the meq gene were synthesized in the presence of digoxigenin-labbeled UTP by using the DIG RNA labeling kit (Roche Diagnostics) according to the manufacturer's instructions. The primers used for making each probe were M-S (5'-ATGTCTCAGGAGCCAGAGCCGGGCGCT-3') and M-AS (5'-GGGGCATAGACGATGTGCTGCTGAG-3') as described previously [42]. The RNA probes (designated meq-sense and meqantisense) were stored at $-80^{\circ} \mathrm{C}$ until use. The kidney sample including tumor lesions and spleen samples were fixed in $4 \%$ paraformaldehyde (PFA) overnight at $4^{\circ} \mathrm{C}$ and paraffin sections $(0.4 \mu \mathrm{m}$ thick) were then prepared. Deparaffinized, proteinase $\mathrm{K}$-digested sections were incubated with a prehybridization solution and then incubated with hybridization buffer containing 50\% formamide, $10 \mathrm{mM}$ Tris- $\mathrm{HCl}$ pH 7.4, $200 \mu \mathrm{g} / \mathrm{ml}$ tRNA, $1 \times$ Denhardt's solution (0.02\% bovine serum albumin, $0.02 \%$ polyvinylpyrrolidone, and $0.02 \%$ Ficoll PM400 (Amersham Pharmacia, Uppsala, Sweden)), 10\% dextran sulphate, $0.25 \%$ sodium dodecyl sulphate, $1 \mathrm{mM}$ ethylenediamine tetraacetic acid $\mathrm{pH}$ 8.0, and $50 \mathrm{ng}$ of sense or antisense RNA probe overnight at $58^{\circ} \mathrm{C}$. The sections were incubated in an anti-DIG conjugated to alkaline phosphatase (1:400; Roche Diagnostics) overnight at room temperature (RT). The signal was detected by incubation of the sections with substrate solution containing nitroblue tetrazolium/ X-phosphate in a solution composed of $100 \mathrm{mM}$ Tris- $\mathrm{HCl}$ (pH 9.5), $100 \mathrm{mM} \mathrm{NaCl}$, and $50 \mathrm{mM} \mathrm{MgCl}_{2}$ in a dark room overnight at RT.

\section{RT-PCR or nested RT-PCR assay of laser-captured microdissections}

The organs were fixed with 4\% PFA and embedded to paraffin for laser microdissection (LMD). LMD was performed as previously reported [43]. First, $5 \mu \mathrm{m}$-thick paraffin sections were mounted on glass slides precoated with LMD films (Meiwafosis, Tokyo, Japan), deparaffinized by xylene, and dehydrated by alcohol. After staining with $1 \%$ toluidine blue for $5 \mathrm{sec}$, LMD was performed on the normal renal cortices and tumorigenic lesions by using Ls-Pro300 (Meiwafosis), according to the manufacturer's protocol. All procedures were performed in RNase-free conditions.

Total RNA purified with RNAqueous (Ambion, Austin, TX, USA) was reverse-transcribed to cDNA by using SuperScript First-Strand Synthesis System for RT-PCR (Invitrogen) according to the manufacturer's protocol. Synthesized cDNA was used for the PCR or nested PCR with TAKARA-Taq (Takara) and appropriate primer pairs (Table 1). Reactions were started with $94^{\circ} \mathrm{C}$ for $5 \mathrm{~min}$, followed by 40 cycles of $94^{\circ} \mathrm{C}$ for $30 \mathrm{sec}$, each annealing temperature (shown in Table 1) for $30 \mathrm{sec}$ and $72^{\circ} \mathrm{C}$ for $30 \mathrm{sec}$, and $\mathrm{f} 72^{\circ} \mathrm{C}$ for $7 \mathrm{~min}$, and finally kept at $4^{\circ} \mathrm{C}$. Nested PCR analysis was performed by using $1 \mu \mathrm{l}$ of the 1 st PCR reaction as a template and in a $20 \mu \mathrm{l}$ reaction mixture. The amplified fragments were separated on agarose gels (2.0\%) and visualized under ultraviolet light after staining with ethidium bromide.

\section{Analysis of the immunoinhibitory function in the PD-1/PD-L pathway}

For the construction of plasmids expressing PD-L1, chicken $P D-L 1$ transcript was amplified by PCR using primes PDL1-F-NotI (5'-GGGGCGGCCGCATGATGGAAAAGCTTTTGCTTTTGCAC-3') and PDL1-R-SalI (5' -CCCGTCGACTTTATGCTTACATTTCAGCTCCGCATCTT-3') that added a NotI site to the $5^{\prime}$ end and a SalI site to the $3^{\prime}$ end for cloning. The amplified fragment was digested with NotI and SalI and cloned into the NotI and SalI sites of the pCMV-Tag1 vector (Stratagene, La Jolla, USA) to construct a plasmid expressing PD-L1 (pCMV-PDL1).

DF-1 cells were seeded in 6-well plate at $2 \times 10^{6}$ cells per well in $2.5 \mathrm{ml}$ of D-MEM and incubated at $41^{\circ} \mathrm{C}$ in $5 \% \mathrm{CO}_{2}$ overnight. The cells in each well were transfected with $5 \mu \mathrm{g}$ of pCMV-PDL1 or pCMV-Tag1 using Lipofectamine 2000 (Invitrogen) according to the manufacturer's instructions. At $36 \mathrm{~h}$ post transfection, these DF-1 cells were co-cultured with Lee1 cells at $8 \times 10^{6}$ cells per well in $2.5 \mathrm{ml}$ of RPMI 1640 and incubated at $41^{\circ} \mathrm{C}$ in $5 \% \mathrm{CO}_{2}$ for $12 \mathrm{~h}$. The expression levels of the IFN- $\gamma$ gene in co-cultured Lee1 cells were analyzed by real-time RT-PCR as described above.

\section{Western blotting}

Transfected DF-1 cells were lysed at $48 \mathrm{~h}$ post transfection in $2 \times \mathrm{SDS}$ buffer $(150 \mathrm{mM}$ Tris- $\mathrm{HCl} \mathrm{pH} \mathrm{6.8,4 \%}$ SDS, $10 \%$ 2-mercaptoethanol, $20 \%$ glycerol and $0.2 \%$ bromophenol blue) and boiled for $10 \mathrm{~min}$. Samples were separated on 15\% SDS-polyacrylamide gels and transferred to the polyvinylidene difluoride membranes (Millipore Corp., Bedford, MA, USA). The membranes were blocked overnight at $4^{\circ} \mathrm{C}$ with $0.05 \%$ Tween 20 in phosphate-buffered saline (PBST) containing 3\% skim milk. The membranes were then incubated at RT for $1 \mathrm{~h}$ with goat anti-myc tag antibody (abcam), washed 3 times with PBST, and incubated at RT for $30 \mathrm{~min}$ with peroxidaseconjugated rabbit anti-goat IgG (EY Laboratories). After 3 washes with PBST, the membranes were incubated with 3,3'-diaminobenzidine tetrahydrochloride and cobalt chloride substrates to visualize the peroxidase signal. The blot was also probed with mouse anti-actin monoclonal antibody (Millipore) followed by peroxidase-conjugated goat anti-mouse IgG $(\mathrm{H}+\mathrm{L})$ (Jackson ImmunoRsearch) as a loading and transfer control. 


\section{Additional files}

Additional file 1: Figure S1. Comparison of tumor lesions observed in kidneys with PBMCs obtained from infected or uninfected chickens. A total of 9 tumor samples and PBMCs obtained from tumor-bearing chickens were collected at 21,28 , and 35 d.p.i. $(n=2,3$, and 4 , respectively). Twelve PBMCs obtained from uninfected chickens at 21, 28, and 35 d.p.i. The expressions of PD-1 (A) and PD-L1 (B) mRNA were determined by real-time RT-PCR. The concentration of each mRNA was normalized to that of $\beta$-actin mRNA. Error bars represent standard deviations. The significant differences were determined by Student's $t$-test $\left({ }^{*} P<0.05\right.$, $\left.{ }^{* *} P<0.01\right)$.

Additional file 2: Figure S2. Hypothetical model of PD-1 and PD-L1 involvement in chickens infected with MDV-1. The expression of PD-1 is increased in the early cytolytic phase of the MDV infection, and may be involved in MD pathogenesis including apoptosis of $C D 4^{+} T$ cells. In contrast, the expression of PD-L1 is increased in the latent phase, and may contribute to the establishment and maintenance of MDV-1 latency. Both PD-1 and PD-L1 are expressed on MD tumor cells in the secondary cytolytic phase, and thereby may contribute to the immunosuppression, immune evasion, and tumor development.

\section{Abbreviations}

PD-1: programmed death-1; PD-L: programmed death ligand; MDV: Marek's disease virus; IFN: Interferon; RT-PCR: reverse transcription polymerase chain reaction; HVT: herpesvirus of turkeys; TCR: T cell receptor; HIV: human immunodeficiency virus; HCV: hepatitis C virus; DCs: dendritic cells; HTLV1: human T-cell lymphotropic virus type 1; PBMC: peripheral blood mononuclear cell; REV: reticuloendotheliosis virus; LCMV: Iymphocytic choriomeningitis virus; RT: room temperature; CEF: chicken embryo fibroblast; LMD: laser microdissection.

\section{Competing interests}

The authors declare that they have no competing interests.

\section{Acknowledgements}

This research was supported in part by Grants-in-Aid for Scientific Research (B: 21405034 and 23380176) and Global Centers of Excellence Program from Japan Society for the Promotion of Science, and Grants for Scientific Research from the Akiyama Life Science Foundation of Japan. The funders had no role in study design, data collection and analysis, decision to publish, or preparation of the manuscript. We thank Dr. Akio Enya, Gehn Corp., Gifu, Japan, who kindly provided samples from chickens with MD in poultry farms in Japan.

\section{Author details}

'Department of Disease Control, Graduate School of Veterinary Medicine, Hokkaido University, Kita-18, Nishi-9, Kita-ku, Sapporo 060-0818, Japan. ${ }^{2}$ Department of Biomedical Sciences, Graduate School of Veterinary Medicine, Hokkaido University, Kita-18, Nishi-9, Kita-ku, Sapporo 060-0818, Japan.

\section{Authors' contributions}

AMK and SM carried out study design, most of the experiments, wrote the manuscript, and performed the statistical analysis. MI, RK, ST, and OI helped in vitro experiments. SK, and $\mathrm{KO}$ revised the manuscript. All authors read and approved the final manuscript.

Received: 1 December 2011 Accepted: 21 May 2012

Published: 21 May 2012

\section{References}

1. Schat KA, Nair V: Marek's disease. In Disease of poultry. 12th edition. Edited by Saif YM. lowa: Blackwell Publishing; 2008:452-514.

2. Shek W, Calnek B, Schat K, Chen C: Characterization of Marek's disease virus-infected lymphocytes: discrimination between cytolytically and latently infected cells. J Natl Cancer Inst 1983, 70:485-491.

3. Hunt H, Lupiani B, Miller M, Gimeno I, Lee LF, Parcells MS: Marek's disease virus down-regulates surface expression of MHC (B Complex) Class I (BF) glycoproteins during active but not latent infection of chicken cells Virology 2001, 282:198-205.

4. Morimura T, Ohashi K, Kon Y, Hattori M, Sugimoto C, Onuma M: Apoptosis and CD8-down-regulation in the thymus of chickens infected with Marek's disease virus. Arch Virol 1996, 141:2243-2249.

5. Jones D, Lee L, Liu JL, Kung HJ, Tillotson JK: Marek disease virus encodes a basic-leucine zipper gene resembling the fos/jun oncogenes that is highly expressed in lymphoblastoid tumors. Proc Natl Acad Sci USA 1992, 89:4042-4046.

6. Levy AM, Gilad O, Xia L, Izumiya Y, Choi J, Tsalenko A, Yakhini Z, Witter R, Lee L, Cardona C, Kung HJ: Marek's disease virus Meq transforms chicken cells via the v-Jun transcriptional cascade: a converging transforming pathway for avian oncoviruses. Proc Natl Acad Sci USA 2005, 102:14831-14836

7. Liu JL, Ye Y, Lee LF, Kung HJ: Transforming potential of the herpesvirus oncoprotein MEQ: morphological transformation, serum-independent growth, and inhibition of apoptosis. J Virol 1998, 72:388-395.

8. Lupiani B, Lee LF, Cui X, Gimeno I, Anderson A, Morgan R, Silva R, Witter R, Kung $\mathrm{H}-J$, Reddy SM: Marek's disease virus-encoded Meq gene is involved in transformation of lymphocytes but is dispensable for replication. Proc Natl Acad Sci USA 2004, 101:11815-11820.

9. Witter RL: Increased virulence of Marek's disease virus field isolates. Avian Dis 1997, 41:149-163.

10. Powell PC, Mustill BM, Rennie M: The role of histocompatibility antigens in cell-mediated cytotoxicity against Marek's disease tumour-derived lymphoblastoid cell lines. Avian Pathol 1983, 12:461-468.

11. Abdul-Careem MF, Hunter BD, Parvizi P, Haghighi HR, Thanthrige-Don N, Sharif S: Cytokine gene expression patterns associated with immunization against Marek's disease in chickens. Vaccine 2007, 25:424-432

12. Gruener NH, Lechner F, Jung MC, Diepolder H, Gerlach T, Lauer G, Walker B, Sullivan J, Phillips R, Pape GR, Klenerman P: Sustained dysfunction of antiviral $C D 8^{+} T$ lymphocytes after infection with hepatitis $C$ virus. J Virol 2001, 75:5550-5558.

13. Trautmann L, Janbazian L, Chomont N, Said EA, Gimmig S, Bessette B, Boulassel MR, Delwart E, Sepulveda H, Balderas RS, Routy JP, Haddad EK, Sekaly RP: Upregulation of PD-1 expression on HIV-specific CD8 ${ }^{+}$ T cells leads to reversible immune dysfunction. Nat Med 2006, 12:1198-1202

14. Freeman GJ, Long AJ, Iwai Y, Bourque K, Chernova T, Nishimura H, Fitz $\sqcup$, Malenkovich N, Okazaki T, Byrne MC, Horton HF, Fouser L, Carter L, Ling V, Bowman MR, Carreno BM, Collins M, Wood CR, Honjo T: Engagement of the PD-1 immunoinhibitory receptor by a novel B7 family member leads to negative regulation of lymphocyte activation. J Exp Med 2000, 192:1027-1034.

15. Keir ME, Butte MJ, Freeman GJ, Sharpe AH: PD-1 and its ligands in tolerance and immunity. Annu Rev Immunol 2008, 26:677-704.

16. Keir ME, Francisco LM, Sharpe AH: PD-1 and its ligands in T-cell immunity. Curr Opin Immunol 2007, 19:309-314.

17. Kozako T, Yoshimitsu M, Fujiwara H, Masamoto I, Horai S, White Y, Akimoto M, Suzuki S, Matsushita K, Uozumi K, Tei C, Arima N: PD-1/PD-L1 expression in human T-cell leukemia virus type 1 carriers and adult T-cell leukemia/ lymphoma patients. Leukemia 2009, 23:375-382.

18. Chen LG, Zhang Z, Chen WW, Zhang ZD, Li YG, Shi M, Zhang JY, Chen LP, Wang SD, Wang FS: B7-H1 up-regulation on myeloid dendritic cells significantly suppresses T cell immune function in patients with chronic hepatitis B. J Immunol 2007, 178:6634-6641.

19. Rodríguez-García M, Porichis F, de Jong OG, Levi K, Diefenbach TJ, Lifson JD, Freeman GJ, Walker BD, Kaufmann DE, Kavanagh DG: Expression of PD-L1 and PD-L2 on human macrophages is upregulated by HIV-1 and differentially modulated by IL-10. I Leukoc Biol 2011, 89:507-515.

20. Parvizi P, Andrzejewski K, Read LR, Behboudi S, Sharif S: Expression profiling of genes associated with regulatory functions of T-cell subsets in Marek's disease virus-infected chickens. Avian Pathol 2010, 39:367-373.

21. Latchman Y, Wood CR, Chernova T, Chaudhary D, Borde M, Chernova I, I wai Y, Long AJ, Brown JA, Nunes R, Greenfield EA, Bourque K, Boussiotis VA, Carter LL, Carreno BM, Malenkovich N, Nishimura H, Okazaki T, Honjo T, Sharpe AH, Freeman GJ: PD-L2 is a second ligand for PD-1 and inhibits T cell activation. Nat Immunol 2001, 2:261-268. 
22. Zheng YS, Cui ZZ, Zhao P, Li HM, Liu CY, Tian ZJ, Zhao HK: Effects of reticuloendotheliosis virus and Marek's disease virus infection and co-infection on IFN-gamma production in SPF chickens. J Vet Med Sci 2007, 69:213-216.

23. Muthumani K, Choo AY, Shedlock DJ, Laddy DJ, Sundaram SG, Hirao L, Wu L, Thieu KP, Chung CW, Lankaraman KM, Tebas P, Silvestri G, Weiner DB: Human Immunodeficiency Virus Type 1 Nef Induces Programmed Death 1 Expression through a p38 Mitogen-Activated Protein Kinase-Dependent Mechanism. J Virol 2008, 82:11536-11544.

24. Yao ZQ, King E, Prayther D, Yin D, Moorman J: T cell dysfunction by hepatitis $C$ virus core protein involves PD-1/PDL-1 signaling. Viral Immunol 2007, 20:276-287.

25. Li Y, Sun A, Su S, Zhao P, Cui Z, Zhu H: Deletion of the Meq gene significantly decreases immunosuppression in chickens caused by pathogenic Marek's disease virus. Virol J 2011, 8:2.

26. Barber DL, Wherry EJ, Masopust D, Zhu BG, Allison JP, Sharpe AH, Freeman GJ, Ahmed R: Restoring function in exhausted CD8 T cells during chronic viral infection. Nature 2006, 439:682-687.

27. Urbani S, Amadei B, Tola D, Massari M, Schivazappa S, Missale G, Ferrari C: PD-1 expression in acute hepatitis $C$ virus (HCV) infection is associated with HCV-specific CD8 exhaustion. J Virol 2006, 80:11398-11403.

28. Morimura T, Ohashi K, Kon Y, Hattori M, Sugimoto C, Onuma M: Apoptosis in peripheral CD4 + T cells and thymocytes by Marek's disease virus-infection. Leukemia 1997, 3:206-208.

29. Kaufmann DE, Walker BD: PD-1 and CTLA-4 Inhibitory Cosignaling Pathways in HIV Infection and the Potential for Therapeutic Intervention. J Immunol 2009, 182:5891-5897.

30. Brown JA, Dorfman DM, Ma FR, Sullivan EL, Munoz O, Wood CR, Greenfield EA, Freeman GJ: Blockade of programmed death-1 ligands on dendritic cells enhances T cell activation and cytokine production. J Immunol 2003, 170:1257-1266

31. Le Blanc K, Tammik C, Rosendahl K, Zetterberg E, Ringdén O: HLA expression and immunologic properties of differentiated and undifferentiated mesenchymal stem cells. Exp Hematol 2003, 31:890-896.

32. Chemnitz JM, Eggle D, Driesen J, Classen S, Riley JL, Debey-Pascher S, Beyer $M$, Popov A, Zander T, Schultze JL: RNA fingerprints provide direct evidence for the inhibitory role of TGF beta and PD-1 on $\mathrm{CD}^{+} \mathrm{T}$ cells in Hodgkin lymphoma. Blood 2007, 110:3226-3233.

33. Dorfman DM, Brown JA, Shahsafaei A, Freeman GJ: Programmed death-1 (PD-1) is a marker of germinal center-associated T cells and angioimmunoblastic T-cell lymphoma. Am J Surg Pathol 2006, 30:802-810.

34. Shimauchi T, Kabashima K, Nakashima D, Sugita K, Yamada Y, Hino R, Tokura $Y$ : Augmented expression of programmed death-1 in both neoplastic and non-neoplastic CD4 ${ }^{+}$T-cells in adult T-cell leukemia/lymphoma. Int J Cancer 2007, 121:2585-2590.

35. Osterrieder N, Kamil JP, Schumacher D, Tischer BK, Trapp S: Marek's disease virus: from miasma to model. Nat Rev Microbiol 2006, 4:283-294.

36. Akiyama Y, Kato S: Two cell lines from lymphomas of Marek's disease. Biken J 1974, 17:105-116.

37. Powell PC, Payne LN, Frazier JA, Rennnie M: T lymphoblastoid cell lines from Marek's disease lymphomas. Nature 1974, 251:79-80.

38. Himly M, Foster DN, Bottoli I, lacovoni JS, Vogt PK: The DF-1 chicken fibroblast cell line: transformation induced by diverse oncogenes and cell death resulting from infection by avian leukosis viruses. Virology 1998, 248:295-304

39. Schat KA, Calnek BW, Fabricant J: Characterisation of two highly oncogenic strains of Marek's disease virus. Avian Pathol 1982, 11:593-605.

40. Witter RL, Burmester BR: Differential effect of maternal antibodies on efficacy of cellular and cell-free Marek's disease vaccines. Avian Pathol 1979, 8:145-156.

41. Abdul-Careem MF, Hunter BD, Nagy E, Read LR, Sanei B, Spencer JL, Sharif S: Development of a real-time PCR assay using SYBR Green chemistry for monitoring Marek's disease virus genome load in feather tips. J Virol Methods 2006, 133:34-40.
42. Lee SI, Takagi M, Ohashi K, Sugimoto C, Onuma M: Difference in the meq gene between oncogenic and attenuated strains of Marek's disease virus serotype 1. J Vet Med Sci 2000, 62:287-292.

43. Ichii O, Kamikawa A, Otsuka S, Hashimoto Y, Sasaki N, Endoh D, Kon Y: Overexpression of interferon-activated gene 202 (Ifi202) correlates with the progression of autoimmune glomerulonephritis associated with the MRL chromosome 1. Lupus 2010, 19:897-905.

doi:10.1186/1743-422X-9-94

Cite this article as: Matsuyama-Kato et al:: Molecular characterization of immunoinhibitory factors PD-1/PD-L1 in chickens infected with Marek's disease virus. Virology Journal 2012 9:94.

\section{Submit your next manuscript to BioMed Central and take full advantage of:}

- Convenient online submission

- Thorough peer review

- No space constraints or color figure charges

- Immediate publication on acceptance

- Inclusion in PubMed, CAS, Scopus and Google Scholar

- Research which is freely available for redistribution

Submit your manuscript at www.biomedcentral.com/submit
C BioMed Central 